第 Springer

Kew/

PLANTS PEOPLE

POSSIBILITIES

\title{
Nematodes or Eelworms
}

Author(s): G. Massee

Source: Bulletin of Miscellaneous Information (Royal Botanic Gardens, Kew), Vol. 1913, No. 9 (1913), pp. 343-351

Published by: Springer on behalf of Royal Botanic Gardens, Kew

Stable URL: http://www.jstor.org/stable/4115029

Accessed: 26-06-2016 09:25 UTC

Your use of the JSTOR archive indicates your acceptance of the Terms \& Conditions of Use, available at

http://about.jstor.org/terms

JSTOR is a not-for-profit service that helps scholars, researchers, and students discover, use, and build upon a wide range of content in a trusted digital archive. We use information technology and tools to increase productivity and facilitate new forms of scholarship. For more information about JSTOR, please contact support@jstor.org.

Springer, Royal Botanic Gardens, Kew are collaborating with JSTOR to digitize, preserve and extend access to Bulletin of Miscellaneous Information (Royal Botanic Gardens, Kew) 
late oblongum, apice oblique clavatum, $5-6 \mathrm{~mm}$. longum, intus nudus. Columna latissima, $2 \cdot \tilde{5} \mathrm{~mm}$. longa; antherae stipes superne late triangulari-dilatatus.

BORNEO.

Flowered in the collection of the Hon. N. C. Rothschild, Ashton Wold, Oundle, in October, 1913. The flowers are yellow, spotted with brownish red on the sepals and petals, and striped with similar colour on the side lobes of the lip.

\section{LV.-NEMATODES OR EELWORMS.}

\section{G. Massee.}

(With plate.)

Nematodes or Eelworms belong to the class Vermes, which includes earthworms; the latter, however, are much more highly organised than eelworms. Tape worms and liver flukes are also closely related. Nematodes are very numerous and widely distributed in nature. The majority of species are saprophytes, and abound in stagnant water, decaying vegetable matter, manure, soil in damp places, \&c. The vinegar eelworm, Anguillula aceti, is a well-known example of this group. The saprophytic species are not at all injurious to living animals or plants, and may be looked upon as scavengers in a small way, causing the disintegration of organic matter, and rendering it once more available for plant life. On the other hand, certain nematodes are parasitic on animals or plants. Trichina spiralis forms very minute, white, chalky looking lumps in the flesh of pigs, and was the cause of a scare some years ago, when it was reported that the parasite might prove a source of danger to human beings; many kinds of worms infesting human beings are also nematodes. The majority of nematodes are long and slender or eel-like in shape during some stage of their development, hence the popular name, eelworm, this, however, is merely a book-name, as with few exceptions they are so very minute that they cannot be seen with the naked eye. Not more than half-a-dozen kinds of eelworms are destructive to plants in this country, but the amount of acknowledged injury caused by their presence is enormous, and it is practically certain that many diseases usually attributed to other causes are primarily due to eelworms. As an example, several diseases of violets, especially when grown in frames, and usually attributed to fungi, are in reality due to the presence of eelworms in the root, where they form minute galls, which contort and destroy the continuity of the water-conducting cells. The plant is as a consequence deprived of the necessary amount of water and food, and the foliage is inclined to wilt, when it is readily attacked by various kinds of fungi, which have been proved by experiments to be unable to infect normal and healthy violet plants.

A quarter of a century ago, with a few notable exceptions such as rust of wheat, \&c., fungi were not credited with being active agents in causing injury to plants; at the present day the pendulum has 
swung to the opposite extreme, and fungi are gravely suspected as being the cause of almost every important disease attacking plants of economic value. Epidemics caused by fungi among wild plants in a state of nature are practically unknown. It will, I believe, be generally admitted that plants cultivated under glass are much more susceptible to attacks from fungi than when the same kinds of plants are grown out of doors, in fact I usually fail to infect plants growing in the open with spores obtained from the same kinds suffering from an epidemic when grown under glass. A good deal of evidence could be given on the same lines, to show that fungi are not so much to blame as is usually supposed for being the primary cause of plant diseases. Experience has proved that fungi undoubtedly are the cause of an enormous loss to cultivators of plants, either as primary or secondary agents, and as the injury caused by the fungus is much more obvious than that produced by the primary cause, it is usually concluded that the injury is entirely due to the fungus, whereas in reality, but for the road being made clear by the primary agent, the fungus, which completes the work of destruction, could not have gained a foothold. For the above reasons I am led to consider that attention to fungi alone is but a poor equipment for a post as plant pathologist, and will not lead to a reduction of the losses caused indirectly by fungi, which can never be exterminated.

Among the known primary agents which enable the large class of fungi known as wound-parasites or facultative parasites to gain an entrance into plant tissues may be enumerated insects of various kinds, which by eating, and more especially by simply puncturing the tissues, enable the germ-tubes of spores to gain a foothold, at first by obtaining food from the injured cells and living as saprophytes, then gradually assuming a parasitic habit and invading the living tissues of the host-plant. In many instances not only do insects-aphides, mites, scale-insects, \&c., enable the fungus to gain an entrance into a plant, but they also unconsciously carry and deposit the spores of the fungus in the punctures made. Injury caused to young leaves and tender shoots by hail is frequently followed by an epidemic, fungus spores germinating readily on the bruised tissues. Clirratic conditions are a most important factor in determining the presence or absence of epidemics due to fungi ; marked contrasts in temperature during the spring months invariably mean an excess of injury caused by fungi, whereas an equable temperature during the same period is marked by a comparative absence of disease. The same applies if extremes of temperature occur between day and night in conservatories, \&c. I have frequently cultivated fungi, Botrytis, Fusarium, Trichothecium, that have commenced their parasitic career in old, partly decomposed nodules on the roots of leguminous plants.

The above remarks, of course, apply to the great number of fungi oscillating between parasites and saprophytes, and which only become true parasites under special circumstances. The extension of disease due to fungi is favoured in many ways by modern methods of cultivation as the marked extension of fungi in space is facilitated by rapid transit. In this respect opportunity is a factor of primary importance. I think it may be stated, without fear of contradiction, that no living 
organism, in a state of nature, enjoys the opportunity of performing all that it is capable of doing. The constant struggle for existence, or whatever phrase be preferred, that compels every animal and plant to be content with the mean, or give and take policy, prevents the accomplishment of such an ideal. Even the fittest, judged from the standpoint of number of individuals and distribution in space, are amendable to opportunity. If this argument be sound, it follows that the extension of disease amongst cultivated plants, nay even the creation of new diseases, due to fungi, should be great, cas the opportunities indirectly and unknowingly, to most people, are many and far reaching. As it has been abundantly demonstrated, that the education of a saprophytic fungus to change its nature, and become a rampant parasite, is a simple matter in the laboratory, it may be assumed that when facilities are offered outside the laboratory the same change would be effected. Among such opportunities for ordinarily saprophytic fungi to change their mode of life may be mentioned the constant wounding of plants, due to careless planting, "heeling in," grass-cutting machines injuring roots, pruning, \&c. The principal reason why there are no epidemics due to fungi in virgin forests and uncultivated places is because host and parasite have lived together for an indefinite period of time, and by a process of elimination the survivors are able to live side by side without either being capable of exercising any very marked superiority. On the other hand, when a new and strange plant is introduced into a virgin forest or to a new country the inevitable epidemic caused by fungi follows. The new importation being altogether unprepared to combat an enemy of which it has had no previous experience at first falls a victim, but as the process of elimination of the least resistent goes on, the epidemic subsides. It is a well-known fact that in the majority of instances the initial period of an epidemic attacking a plant for the first time is most severe after which it gradually subsides. Why? When the hollyhock disease first appeared in Europe it rendered the cultivation of that plant well-nigh impossible. To-day hollyhocks are again in cultivation, and although the rust is present it does no material harm, although the opportunities for infection are ample, in fact much more so than when the epidemic first appeared, as the disease is now met with on malvaceous plants throughout Europe. Again, why? Those elusive conditions of the host-plant appear to offer the most promising field for research, where the primary object is that of reducing the loss directly or indirectly due to fungi. Judging from results, the so-called life histories of fungi, apart from the host, are not likely to lead to the desired result.

To return to eelworms.

Heterodera radicicola, Mull., the gall-forming eelworm, is best known, and does the greatest amount of damage in this country. The egg is large in size, compared with the worm, colourless, elliptic-oblong, about $\frac{1}{50}$ of an inch in length. The covering is very thin and translucent, so that at a certain stage the minute worm can be distinctly seen in its interior. Although so thin the wall is very tough and resistant to extremes of heat and cold, chemical substances, \&c., and the germ is with difficulty killed. The worm usually escapes from the egg in the gall, and is a tiny 
eel-like body quite invisible to the naked eye. The young worms soon find their way into the soil, when they at once proceed to attack any other rootlets that may be present. Should the rootlets not be forthcoming, according to Stone and Smith, they are capable of existing for a considerable time without change, awaiting an opportunity for further development. Having effected an entrance into a young root, aided by means of a moveable spear-like body situated within the mouth-opening, and the whole body becoming immersed in the tissues, the worm comes to rest, and undergoes some remarkable changes. Briefly, in both males and females the body becomes swollen at the centre until it is spindle-shaped. Afterwards the male again assumes an eel-like form, whereas the female continues to enlarge and becomes more or less lemon-shaped. At this stage fertilisation is supposed to take place, after which the males perish, and the stationary females produce numerous eggs in their interior. When the eggs are mature the female dies. Sections of a gall at this stage shows the more or less spherical bodies of the females crowded with eggs, the body showing as a whitish speck to the naked eye. Usually several bodies of distended females may be seen in one section, as they are more or less gregarious in habit. The .swollen portions or galls vary much in size on different plants. On vine roots they are usually small, rarely exceeding the size of a pea; on the tomato they are frequently the size of a marble, whereas on some plants the galls are as large as a walnut or even larger. 'The galls are always formed on the root or on some underground part of the plant. In a section through a gall the vascular bundles and water-conducting vessels will be seen to present a contorted and dislocated appearance. When galls are numerous on the root, as is usually the case, the root is prevented from performing its function of supplying the above-ground portion with water containing food substances in solution, consequently the plant literally dies of hunger and thirst, as is also the case when the passage of water is interrupted by the presence of fungus mycelium in the tissues of the root and collar.

There appears to be little or no discrimination in the choice of a tood-plant by nematodes; Kühn, a German observer, enumerates a list of 180 plants, belonging to 39 orders ; amongst these grasses are most favoured, 46 species being attacked by eelworms; Leguminosae 33 kinds, \&c. Eelworms may be commonly found infesting wild grasses in this country, hence the popular idea that turf from an old pasture is perfectly free from eelworms and other pests, is not necessarily correct.

In this country cucumbers and tomatoes suffer most severely from the ravages of eelworms ; this, however, is not due to any special preference on the part of eelworms for these plants, but is simply due to the method of cultivation under glass, where the soil becomes infected, and only half-hearted measures are adopted for the purpose of securing immunity from a pest admittedly difficult to exterminate. Among other plants of economic importance attacked by $\boldsymbol{H}$. radicicola are vines, potatoes (tubers), roses, Phloxes and Balsams ; less frequently fruit trees are attacked; but, as already stated, in the case of stunting of the foliage, the absence of thriftiness, 
or wilting, the presence of eelworms in the root may be suspected, whatever kind of plant may be concerned. The most obvious indication of the presence of eelworms is the galled or knotted appearance of the root. This, however, is but a suggestion, and should be corroborated by microscopic examination, as galls on the root may be due to other causes, For example, the swellings on the roots of cabbages, caused by the cabbage root fly, Phorbia brassicae ; finger-and-toe, on the roots of various cruciferous plants, due to the presence of Plasmodiophora brassicae, \&c. Tubercles are normally present on the roots of leguminous plants, but galls formed by nematodes may often be found intermixed on the same root.

So far as preventive or curative methods are concerned, there is no known method by which the eggs of eelworms can be killed in open ground, and even when treating a limited amount of soil in houses, the most drastic measures, accurately applied, can alone command success. The reăson why eelworms are so difficult to exterminate arises from the fact that eggs are produced in immense numbers throughout the year, or at all events so long as living roots are available, and young eelworms are constantly being likerated into the soil, consequently the dressing capable of killing eelworms should be repeated for a considerable number of times, extending over a long period of time, which becomes almost impracticable. A dressing of sulphate of potash, $3 \mathrm{cwt}$. per acre, will kill all active eelworms with which it comes in contact, and however well it may be worked into the soil many will escape, and its efficacy soon passes away. When, however, a growing crop is suffering from eelworm, the application of sulphate of potash, if at a sufficiently early date, will check the progress of the disease to some extent, but it will not prove a permanent cure, since the eggs are not destroyed. The application of lime is practically useless against eelworm. Gaslime, now hardly procurable, is a more satisfactory remedy, as its lasting power in the land means the death of successive generations, but to obtain this end the land must lie fallow for some time. The use of a "trap crop" is advocated by German experts, where the injury to sugar-beet by eelworm is often considerable. The idea of a trap crop is to grow on infected land some plant readily attacked by eelworms, the crops should be pulled up and sun-dried, if practicable, when a considerable number of larval nematodes have entered the roots, and before a new brood is produced ; summer rape is recommended for this purpose, on account of its quick growth and great spread of root. Success of course entirely depends on the removal of the crop at the proper time. This method so far reduces the number of eelworms present in the land that a fairly good crop may be secured, but its effect is not lasting.

For the complete destruction of eelworms in soil in tomato and cucumber houses, \&c., the method recommended by Stone and Smith is as follows :-

"The most effectual, complete, and practical method at the present time of exterminating nematodes in greenhouses is by heating the soil by means of steam. This can be accomplished without much expense providing proper attention is paid to the method of applying the steam. A pressure of steam exceeding $50 \mathrm{lbs}$. is not only 
cheaper but more effective than a pressure which falls below this, and the amount and cross section area of the tile [pipe] is important. The cost of heating soil depends upon the equipment employed and cost of labour, \&c. Probably not far from 100 cubic feet of soil under the most favourable conditions can be heated in one hour's time to a temperature of over $200^{\circ} \mathrm{F}$. The minimum amount of heat necessary to kill nematodes and their eggs while confined to the soil is about $140^{\circ} \mathrm{F}$., but for all practical purposes it is desirable to make use of a higher temperature, at least from $180^{\circ}-212^{\circ} \mathrm{F}$. 'The benefit ö̈ steaming or sterilising soil is not alone confined to nematodes. Many other greenhouse pests are killed. The mechanical conditions of the soil are moreover greatly improved, the numerous compounds are rendered more available for plant food, which results in giving plants grown in a sterilised soil a considerable acceleration in their rate of growth." Full details and plans relating to the sterilisation of soil by steam, are given in Bull. No. 55, Hatch Experiment Station, Mass., U.S.A.

It has been suggested that dressing the soil with rape meal destroys eelworms. This may possibly hold in check or kill active eelworms, but it will not kill the eggs.

It is well known that a poor physical condition of the soil not only favours the spread of eelworms, but also prevents their destruction, owing to the difficulty of diffusion and permeation of the remedial agent applied.

Potassium permanganate, 1 part in 200 parts, kills eelworms, if the soil is saturated at intervals of ten days, and does not injure growing plants. This again may be used to save a growing crop, but as it has no effect on the eggs, it must not be depended upon for exterminating the pests. Finally, carbon bisulphide injected into the soil will kill any active eelworms present.

Heterodera schachtii, Schm.-The sugar beet eelworm differs from $\boldsymbol{H}$. radicicola in not forming galls or knots on the roots of the hostplant. The young females only penetrate the peripheral layer of the rootlet, and on increasing in size burst through to the surface, remaining attached by a narrowed portion only, hence an attacked rootlet presents a knotted appearance, figs. 1 and 8 , the knots being the external distended females and not galls of plant tissue. $H$. schachtii is a serious pest in the sugar beet fields in Germany, but up to the present, so far as I am aware, has not been recorded on sugar beet in this country. Quite recently, however, $H$. schachtii has proved destructive to. potatoes in Scotland, where the rootlets are attacked in a similar manner to the rootlets of sugar beet, fig. 8. This discovery is of some importance, as plants belonging to Solanaceae, Papaveraceae, Compositae and Umbelliferae respectively are stated by Voigt to be free from the attacks of this pest. Potatoes have been recommended for growing on infested beet-growing land, along with a trap crop of rape, for the double purpose of obtaining a crop and reducing the number of eelworms at the same time. It certainly would not be wise to follow this course in Great Britain. It may be stated that Oospora scabies, a fungus causing a scab on potato tubers, also attacks sugar beet, which is an additional reason why these two crops should not alternate, as $O$. scabies 
when once introduced into the land is somewhat difficult to eradicate. When sugar beet is attacked in the seedling or young stage, the formation of a tap-root is arrested, and several long, slender rootlets take its place, to which numerous distended female eelworms are attached, fig. 1. This eelworm has been observed on about 50 different kinds of plants, among which may be mentioned, mangolds, cabbages, radish, spinach, Agrostemma githago, \&c. The treatment for the destruction of this eelworm is the same as for $H$. radicicola.

Tylenchus devastatrix, Ritzema Bos, is a third eelworm which often proves very injurious to several outdoor crops. Clover sickness, which is frequently attributed to the exhaustion of some ingredient of the soil necessary for the growth of clover, is in reality caused by this eelworm. The symptoms are a yellowing of small, usually scattered patches; these patches gradually increase in size, and according to the severity of the attack, and the rate of spread of the eelworms through the soil, the crop becomes more or less involved. In the end the attacked plants become brown and dead, leaving bare patches in the field. A clover plant infested with eelworms presents a very characteristic appearance. The branches, where they spring from the root, are very much swollen and often distorted, whereas in the normal plant the branches are thin and wiry. A section through the swollen part reveals the presence of female eelworms or their eggs. If the diseased patches are observed when quite small, dig up the plants and burn them on the spot when dry, taking care to remove the plants well beyond the zone of apparent injury. Then dress with sulphate of potash as previously advised.

"Segging" of oats, or "Tulip root," is also caused by Tylenchus devastatrix. The symptoms are the swollen appearance at the base of the culm, which bears a number of swollen distorted shoots. Diseased plants remain stunted and eelworms or their eggs will be found in the swollen parts. Deep ploughing, where allowable from other standpoints, and treatment by sulphate of potash are recommended for infected land, which should not be sown with a crop susceptible to the disease such as clover. Barley or root crops are safe.

Microscopic examination is necessary for the certain determination of the presence of eelworm, as the base of the culm in oats is also swollen in a similar manner when attacked by the frit fly (Oscinis frit).

The same eelworm is the cause of a disease of the strawberry plant. The plants rot and decay at the ground level and the leaves are often crinkled and deformed at an early stage. Diseased plants should be removed and burned, and the land treated with sulphate of potash.

Aphelenchus fragariae, Ritzema Bos. is the cause of a second disease of strawberry plants, known as the "cauliflower" disease, Diseased plants present a fasciated appearance, the stems and leaves being consolidated into an irregular fleshy mass, suggesting 
a cauliflower. The flowers also assume monstrous forms. Diseased plants should be removed and sulphate of potash applied.

Tylenchus tritici, Bastian, the cause of "Ear-cockles" of wheat, is sometimes responsible for a considerable shortage of the wheat crop. The grain, which is the part attacked, becomes changed into a roundish, blackish-purple mass, somewhat smaller in size than a normal grain. As a rule almost every grain in the ear is attacked. When a diseased grain is crushed and examined under the microscope numerous eelworms will be seen wriggling about in a characteristic manner. A similar temporary wriggling occurs when infected grains, that are over fifty years old and have been kept perfectly dry all the time, are crushed and placed in water. This was at one time supposed to demonstrate the extreme vitality of life under desiccation. Such eelworms, however, are dead, and the wriggling is simply due to the absorption of water by their desiccated bodies, which causes them to expand. When the body of an eelworm is once saturated with water and properly expanded all movement ceases. This phenomenon is clearly shown in specimens of " earcockle" grains included in a pioneer work on plant diseases, by Edwin Sidney, entitled "Blights of the Wheat, and their remedies," 1846.

When infected grains are sown together with healthy ones, they become soft, and the eelworms escaping into the ground make their way to the sprouting wheat, and insert themselves under the leaf-sheaths, where they remain until the ear begins to develop; when they enter the soft, young grain, and a gall or ear-cockle results.

If seed grain containing ear-cockles is placed in water, and well stirred up, the lighter, diseased grains float, and can be skimmed off.

Aphelenchus olesistus, Ritzema Bos, the Fern eelworm, forms brown streaks or patches on the living fronds of various kinds of ferns. The shape of the brown patches is determined by the venation of the particular fern attacked. Where the veins are more or less parallel, as in Lygodium, Pteris, \&c, the blotches are long and narrow, extending from the mid-rib to the margin of the pinnule; where the veins anastomose irregularly the blotches are more or less angular. This is due to the fact that the eelworms in the tissues of a fern frond cannot penetrate beyond the portion circumscribed by a vein. When the air is moist the eelworms leave old patches and enter adjoining healthy parts through the stomata. When the air is fairly dry, this migration is checked. In addition to ferns, this eelworm attacks the leaves of many kinds of flowering plants, Chrysanthemum, Begonia, Calceolaria, Gloxinia, Coleus, \&c, forming more or less extended brown patches, frequently mistaken for the injury done by Thrips. This eelworm breeds in the soil, and enters the leaves of the plants for food only. Treating the soil with carbon bisulphide kills the eelworms, but not their eggs, hence the treatment must be constantly repeated until the pest is exterminated. Dusting the under surface of the leaves, and more especially the stems near the ground, with a mixture of tobacco powder and flowers of sulphur, when moist, will prevent the eelworms from ascending and entering the tissues. 


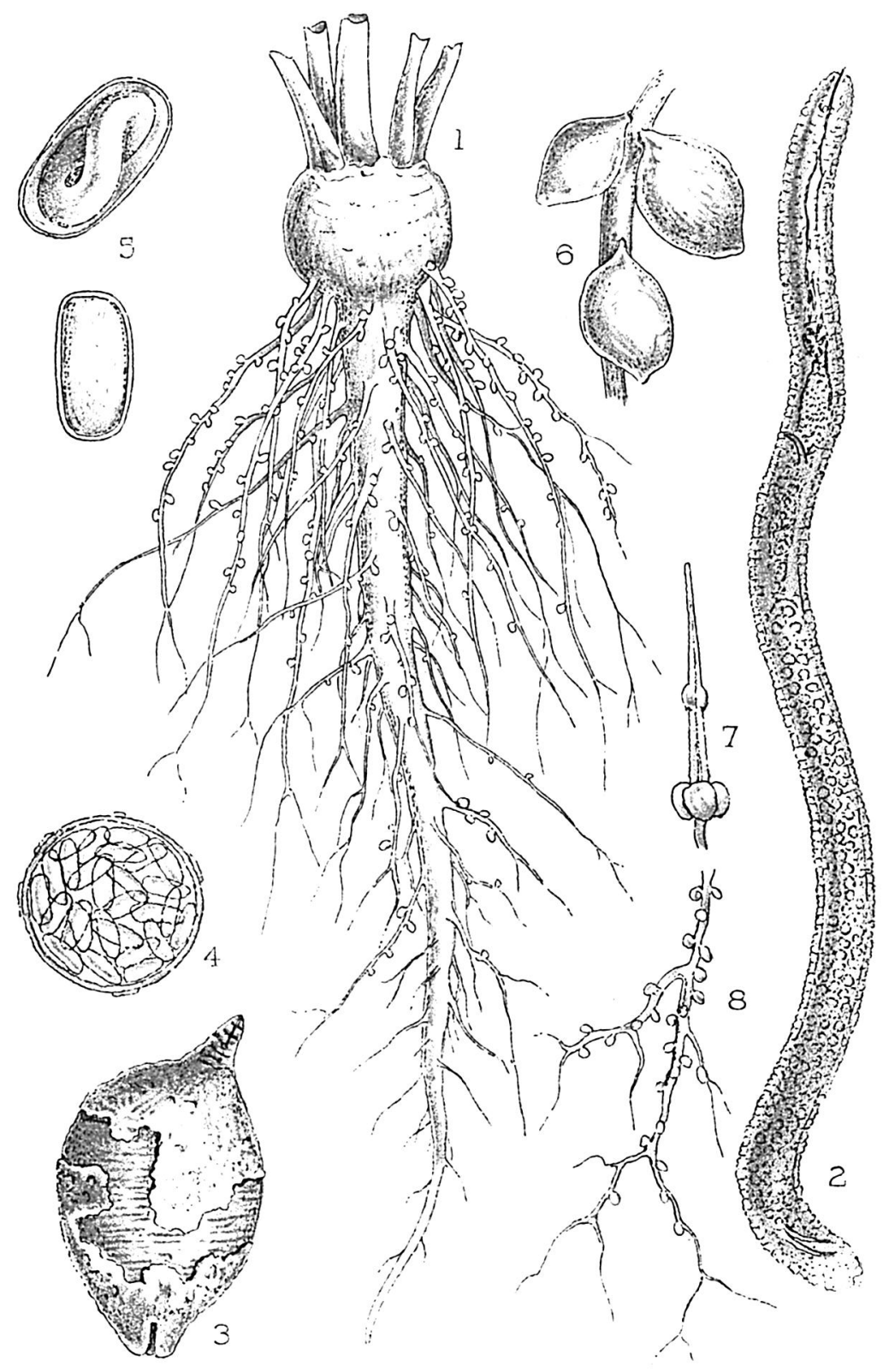

Sugar beet Eelworm. 
Aphelenchus olesistus has caused considerable trouble in the fern houses at Kew. A short account of this eelworm was given in $K . B ., 1909$, pp. 243, 244, and the accompanying text figure is reproduced from that volume. Aneimia collina, Pteris Droogmantiana, Adiantum Capillus-veneris, and Lygodium volubile have been among the ferns more particularly attacked.

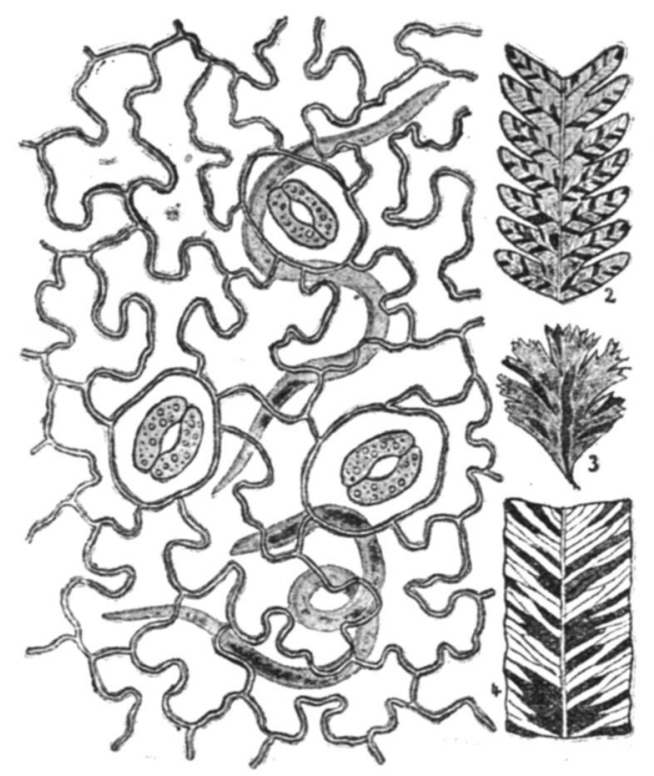

Fig. 1. Aneimia collina, Raddi, showing the eelworms in the tissue of the frond under the epidermis $\times 300$.

Fig. 2. Pteris Droogmantiana, L. Linden. The dark streaks are caused by the eelworm.

Fig. 3. Adiantum Capillus-veneris, f. fissa, showing dark patches due to eelworm.

Fig. 4. Lygodium volubile, Sw., with dark streaks caused by eelworm.

\section{Explanation of Figures in Plate. \\ Heterodera schachtii, Schm.}

1. Young sugar beet attacked by eelworm. Nat. size.

2. Male of sugar beet eelworm. $\times 500$.

3. Female of sugar beet eelworm. $\times 500$.

4. Section of female of same filled with eggs. $\times 500$.

5. Eggs of same in different stages of development. $\times 1200$.

6. Female eelworms of sugar beet attached to rootlet of sugar beet. $\times 250$.

7. Spear, or piercing apparatus of eelworm. $\times 1200$,

8. Sugar beet eelworm on rootlets of potato. Nat. size. 